\title{
ANALYSIS OF STATE INVESTMENTS INTO HUMAN CAPITAL IN SLOVAK REPUBLIC
}

\author{
Daniela Palaščáková, Gabriela Kol'veková, Dávid Melas
}

\section{Introduction}

As for creating values in society intellectual capital is as inevitable as money and physical capital. According to Edvinsson and Malone (1997), intellectual capital can be defined as intangible assets, which are not explicitly stated in the company's balance but even though they have a positive effect on the company's efficiency. The division of elements of the intellectual capital varies across different literature particularly regarding its titles. The same categories are called differently by Edvinsson and Malone (1997), by Petty, Cuganesan, Finch and Ford (2009), by Fragouli (2015) and by others like Ozkan, Cakan and Kayacan (2017). For our purposes, we will use the division that was also used by Ozkan, Cakan, and Kayacan (2017) and according to which intellectual capital consists of these three elements: structural, relational and human capital.

In this article, we focused our attention on the last element of the intellectual capital human capital, which consist of all knowledge, experiences, and skills, that employees have (Ozkan et al., 2017). In the context of human capital, we will comprehend this issue in broader connection with upbringing and education because educational systems should respond to recent global problems. Their goal is to form full-valued graduates of each grade and types of schools, ready to fulfil their professional and personal tasks in their future lives. One of the possible approaches that can solve the negative effects of the changing, globalized world is implementing global development education into academical education.

Countries, in order to benefit from Global Value Chains (GVCs), must invest more into education and professional training, use the skills better, further coordinate their policy in the field of skills - from the policy of education and migration to employment protection legislation - and harmonize these policies with industrial and business policy.

According to Koisova et al. (Koisova, Masarova, \& Habanik, 2018), the labour market is working with the most precious capital of the economy, the human capital, which is also the carrier of labour. The human capital has always played an important role in the social development and the achievement and stabilisation of economic growth (Gavurova, Soltes, \& Kovac, 2017). „With an emphasis on stabilisation of economic growth, it is an essential part of the modern state to provide more incentives for job searching and to increase the competitiveness of Active Labour Market Policy (ALMP)“ (Bánociová, \& Martinková, 2017) and to prepare „a favourable business environment in which the state supports and protects economic competition, creates clear and stable rules, and effectively ensures compliance by all market participants while minimizing administrative barriers towards entrepreneurs".

The human capital increase has a positive effect on other factors of increase, stimulates technological progress (Galor \& Tsiddon, 1997), supports indirectly growth of the physical capital (Dobeš, 2000) and positively influences employment.

According to OECD (2017), Korea and Poland which started from different starting points, have increased their involvement in GVCs in the last 15 years. They specialized more on technologically developed fields and at the same time they have been improving the skills of their population and that's how they increased the economic and social profit rate and so they had benefited from GVCs.

Chile and Turkey have also increased their involvement in GVCs significantly as they have developed their skills necessary for the solving of 
their problems and so they have achieved good results in the field of employment. However, their skills were not harmonized enough with the requirements of technologically developed sectors, which partly explains their low level of specialization in these sectors.

Germany and the USA have significantly increased their involvement into GVCs. However, it seems that German population's skills support the model of specialisation of German industry, which is not the case in the USA to such a big extent.

On the other hand, some countries like Greece, and also Belgium to a certain extent, have integrated weakly into GVCs. They have improved their skills just a little and they didn't use GVCs as a source of economic growth.

Instead of the contest for attracting talented people, countries should cooperate on creating educational programmes and professional training. With this concerted effort, they can ensure quality and maintain the knowledge and skills that countries need if they want to prosper in GVCs. This effort can also increase skills in developing economies and make the recognition of these skills in other countries easier. Countries could consider financial mechanisms that would reflect better the division of gains and costs among the countries of the world, in which there has internationalisation of education and of production process taken place (OECD, 2017).

Why are investments in human capital so important? Investments into education, training and deepening of one's knowledge "portfolio" on individual level increase competence, competitiveness and the probability of higher income, decrease unemployment risk rate, fulfil the need of growth, increase motivation and the ability to enjoy life (Gavurová, Vagasova, \& Kovac, 2016). On a corporate level, these investments increase the employee's productivity, decrease the employee's fluctuation and increase the productivity of physical capital because employees with lots of experiences and knowledge are can better cope with machines and information technologies than employees with poor knowledge, skills, and attainments, who are easily replaceable with machines to do simple tasks (to a certain extent).

This article is focused on state or government investment into human capital and into universities, which are supposed to lead to an increase in wages of individuals after finishing such education. That part of income of graduates which is exceeding incomes of people with finished high school education, i.e. income bonus is, on one hand, a motivational factor for individual to study at university and on the other hand it is an opportunity for the state to achieve higher tax incomes in absolute terms through higher salaries of university graduates and subsequent higher taxes they had to pay. The main goal of this article is to analyse investments into the human capital from the point of view of the amount of investment and its profitability, as well as from the point of view of the payback period for state investments in education.

In connection to this a question arises as to whether graduates, whom we consider as a part of a higher level of human capital, do earn more money on average than people with high school education. Theoretically, employees at the higher level of human capital should be more productive.

\section{Analysis of State Investments in University Education in Slovakia}

Problems of consistent theory regarding concept of human capital were persisting until the 1950s. Until after-war years economists did not pay much attention to the economic analysis of education. Yet, these days the issue of investments in human capital and their consequences is being largely elaborated but it still has not been completed. Many professional and pseudo-professional articles which are concerned with human capital are more prone to recommend investing in employees, students and oneself. One can also find opponents to this belief such as Caplan (2018).

In the mid-1950's there appeared an opinion that it is possible to find causality of income differenciation and education was one of the potential determints. At that time this issue was examined by Milton Friedman - the most significant representative of monetarism and one of the biggest critics of Keynes's teachings. Friedman's and Kuznets's empiric study emphasised the influence of formal education on incomes of individuals. In terms of costs, they took into consideration the sole cost of formal education and also the cost of sacrificed opportunities because of the intense study and training. Excessive avails that individual gains exceed excessive costs. Average wages 
of professional workers i.e. those who have a higher formal education are $85-180 \%$ higher than average wages of nonprofessional workers i.e. those who have a high school education (Friedman \& Kuznets, 1954). Similar ideas were expressed by other authors (Arteaga, 2018; Becker, 1994; Mincer, 1958).

Many authors consider human capital as an asset even though it is not recorded in the balance sheet. However, it meets the formal definition of assets. As Andrejovská (2013) writes: "Assets are economic instruments that are results of past events and from which we expect to lead to increasing economic benefits in the future."

Free education is a great opportunity for students to increase their human capital and their applicability on the labour market. The state supports university education through investments that create conditions for the free education system, for the development of universities but also through the social support of students. These investments are in form of subsidies to public universities provided by the Slovak Ministry of Education (MŠ SR) and sent to individual universities. In case of relevant incentives from universities the subsidies are updated and later approved by the National Fiscal Council as a part of the Law regarding the state's budget.

The total amount of the subsidies to public schools from the state's budget is divided into four categories: 1.) Subsidies to accredited study fields (sub-programme 077 11); 2.) Subsidies for research, development and art activities (sub-programme 077 12); 3.) Subsidies to development of the university (sub-programme 077 13) and 4.) Subsidies to support students (sub-programme 077 15).

If we want to calculate the number of state costs per student during one year we must consider that annual costs per full-time study student will be higher than annual costs per part-time (external) student.

We included costs of sub-programme 077 11 i.e. subsidies for accredited study fields into the calculation of state costs per one student. Wage costs of university employees, insurance costs and levies $(35.2 \%)$ from the previous item and costs of goods and services regarding educative activities of the university.

Other expenditures that we have included in our methodology are incentive scholarships that are a part of the budget of public universities under the sub-program 077 15. We calculated the remaining parts of this sub-program, such as social scholarships and indirect support costs, in a different way because only full-time students are entitled to the benefits secured by those expenses.

Government expenditures for higher education, which we paid no extra attention to, are expenditure under sub-programs 077 12 and 077 13, which represent grants for research, development and arts activities and subsidies for the development of the university. We believe that these activities support and develop the intellectual capital of the university, but they do not interfere with an increase in human capital of students to such an extent that they should be included. Research activities, of course, are inherently a part of pedagogical activities at universities and pedagogues later transfer the knowledge to students. Therefore, it could be said that research activities increase the human capital of the university pedagogues. This increase will be reflected in the pedagogue salary grade, i.e. under sub-program 07711 in one of the following years.

\section{Data and Methodology}

When analyzing the state expenditures for higher education, we used the methodology of the Ministry of Education of the Slovak Republic concerning the distribution of subsidies for the individual sub-programs, which include state expenditures for the implementation of accredited study programs, research and development activities, development of higher education institutions and social aid to students during the monitored period 2008 to 2017 . For the initial analysis, where we asked whether the average of higher educated people earn more than the secondary educated people, we used the data of the Statistical Office of the Slovak Republic for the period 2008 to 2016. We did not include the year 2017 in the analysis because the data at the time of posting for this year have not yet been published. Legislative provisions and budgetary rules on subsidies to public higher education institutions were an important source for us, which helped us to establish a methodology. In particular, it was Law No. 131/2002 Coll. on universities (2002), the methodology for the distribution of subsidies from the state budget to public higher education institutions for the years 2008 to 2017 and Law No. 595/2003 Coll. on income tax (2003). 


\subsection{Methodology for Calculating the Proportion of Sub-Programs 07711 and 07715}

By the number of students, we allocated grants for the implementation of accredited study programs (sub-program 077 11) as follows:

$$
\begin{aligned}
& P D A_{i}=\frac{T G(07711)_{i}}{N S_{i}} \times N S D_{i} \\
& P E A_{i}=\frac{T G(07711)_{i}}{N S_{i}} \times N S E_{i}
\end{aligned}
$$

Where in the year $\mathrm{i}$ :

PDA - The proportion of subsidies for the implementation of accredited study programs for full-time students,

PEA - The proportion of subsidies for the implementation of accredited study programs for part-time students,

TG (077 11) - Total grant for the implementation of accredited study programs,

NS - The total number of students,

NSD - The number of full-time students,

NSE - The number of part-time students.

As a result of this calculation, the proportion of government expenditures spent on the implementation of accredited study programs will be proportional to all students of the daily (full-time) and external study (part-time) in the reference year $i$. If we only divide the total subsidy for sub-program 07711 by the total number of students, we will get the portion of the grant for implementing accredited programs per one-student (ASPS) that we needed to calculate the total expenditure expanded by the state per student.

As part of the subsidy for social support for students (sub-program 077 15), the calculation of government expenditure per student is slightly more complicated. This is mainly because part-time students are not entitled to some benefits provided from state budget funds, while full-time students can access and are entitled to these benefits. In particular, these are the following benefits:

- Social scholarship - according to Act No. 131/2002 Coll. on Higher Education Institutions, namely $\S 96$ para. Article 2 (e) - a student is not entitled to a social scholarship if he/she is studying in an external form of study.

- Costs of catering - according to the methodology of the subsidy schedule, only students of full-time study, including $\mathrm{PhD}$ students, are entitled to this contribution.

- Accommodation allowance - is a part of the social support of students who are eligible for the social scholarship according to the Higher Education Act. Thus, according to Section 96 of the Higher Education Act, students of the external form of study are not eligible for this allowance.

- Financial contribution to the expenditures of sports and cultural activities - on the basis of the methodology of subsidy distribution, students of an external form of study are not entitled to a financial contribution related to organizational support for sports and cultural activities.

Doctoral students, i.e. III. University degree students have specially allocated funds for incentive scholarships within the university budget. However, we were forced to neglect these because, in the last years of the period under review, these funds have been included in the research, development and artistic activity subsidy, and its amount is not clear from the available data. Entitlement to incentive scholarships is available to all students in both the daily and the external forms of study, and therefore we calculated the proportional part of the incentive scholarship for the students of the daily and the external form of study. In the same way, we calculated the proportion in the previous case as we neglected of the students of the third university degree, who have separate scholarships from the students of the first and the second university degree in the methodology. In 2016, the methodology changed and doctoral scholarships are paid out from a university budget, and not from the state subsidy. To do this, we can compare the Methodology of Grant Subsidy from the State Budget for 2016 and the Methodology of Grant Subsidies from the State Budget for 2015.

$$
\begin{aligned}
& P F M_{i}=\frac{T S M_{i}}{N S_{i}-N F C_{i}} x N S F_{i} \\
& P E M_{i}=\frac{T S M_{i}}{N S_{i}-N F C_{i}} \times N S E_{i}
\end{aligned}
$$

Where in the year $i$ :

PFM - The proportion of expenditure on motivational scholarships for full-time students, PEM - The proportion of expenditure on motivational scholarships for part-time students, TSM -A total subsidy for motivation scholarships, NS - The total number of students, 
NSF - The number of full-time students,

NSE - The number of part-time students,

NFC - Number of PhD candidates in the fulltime study.

As in the previous case, grants for incentive scholarships for one student in a full-time course of study (full-time student) and one student in an external form of study (part-time student) will be equal. We will call this section ISS (Insentive Scholarship Subsidies).

Part of sub-program 07715 - Subsidies for social support for students eligible only for full-time students will be the difference between government expenditure per student in the full-time study and per one external study student. We will call it SOC (Social Subsidies). Expenditures per student per year we calculated from the following formula:

SOC $_{i}=\frac{\text { Total amount of sub-programme } 07715-\text { Incentive scholarships }}{i}$

Annual costs incurred through government grants to one student in the full-time study were calculated as the sum of the grant for the purpose of implementing accredited study programs per one student, subsidies for onestudent incentive scholarships and one student social security subsidies. It is easier to see through the following equation:

$$
\mathrm{TAEF}_{i}=A S P S_{i}+\mathrm{ISS}_{i}+S O C_{i}
$$

Where in the year $i$ :

TAEF - Total annual state expenditure per student of full-time study,

ASPS - Annual grants for the implementation of accredited study programs per one student,

ISS - Annual subsidies for incentive scholarships per student,

SOC - Annual subsidies for social support for students of full-time study.

The annual costs incurred for one student in the external form of the study were calculated in the same way except for social support. Part-time students are not eligible for these contributions.

$$
T A E E_{i}=A S P S_{i}+I S S_{i}
$$

Where in the year $i$ :

TAEE - Total annual state expenditure per student in the external form of the study,
ASPS - Annual grants for the implementation of accredited study programs per one student, ISS - Annual subsidies for incentive scholarships per student.

\subsection{Methodology of Calculation of the Rate of Return and Period of Return of State Investment in Education}

To calculate the return on government investment in higher education in the form of grants to higher education institutions, we used a simplified calculation method adjusted to our needs, which considers values of individuals ' average earnings in different education categories. We focused mainly on the categories of high school and university educated people, although we included people with primary education for comparison.

The state's return on investment in education is measured through income tax on college graduates. This return will be different for full-time students, and for part-time students, who, as mentioned earlier, are not entitled to certain benefits financed from the state budget, and therefore represent a lower burden for the state budget. Furthermore, they pay income tax during the course of the study.

In addition to the benefits already mentioned, there are other differences between these two forms of studies and therefore a correction has to be made. This is, in particular, the neglect of these two facts:

1. The fact that the students of the external form of study pay for their studies is not taken into account in our analysis because of the tuition fees and fees associated with the study, based on $\S 92$ par. 19 of Act No. 131/2002 Coll. about higher education institutions, are the income of a university, and not of the state. Therefore, the fees cannot be considered as revenue to the state budget.

2. The fact that at the moment, the external form of study is extended by one year at each stage. In 2016, which is the last year in our analysis, both forms of the study were equally long, i.e. five years, so the length of the study is taken as five years into the calculations.

The full-time study students' return on investment was calculated from the adjusted relationship:

$$
r_{d}=\frac{T_{W_{k}}-T_{W_{k-1}}}{S\left(T_{W_{k-1}}+C_{k d}\right)}
$$


Where:

$\mathrm{TW}_{\mathrm{k}}$ - Annual income taxes of a university graduate,

$\mathrm{TW}_{\mathrm{k}-1}$ - Annual income taxes of a person with secondary education,

$S$ - Years of study,

$\mathrm{C}_{\mathrm{kd}}$ - The average government expenditure per one full-time student over the immediately preceding 5 years,

$r_{d}-$ The rate of return on state investment in higher education system per full-time study student.

The return on investments in external study students was calculated from the adjusted formula:

$$
r_{e}=\frac{T_{W_{k}}-T_{W_{k-1}}}{S * C_{k e}}
$$

Where:

$\mathrm{TW}_{\mathrm{k}}$ - Annual income taxes of a university graduate,

$\mathrm{TW}_{\mathrm{k}-1}-$ Yearly income tax of a person with secondary education,

$S$ - Years of study,

$C_{k e}$ - The average of government expenditure per one part-time student for the immediate previous 5 years,

$r_{e}$ - The rate of return on state investment in higher education to a student of the external form of study.

We used the data published by the Ministry of Education of the Slovak Republic and by the EU-SILC data published by Eurostat.

\section{Results}

In Tab. 1 we projected the total amount of state subsidies, which was based on the calculation of the costs of education for one student studying in the full-time study and the external form of study during the reference year $i$. The total amount consists of the sum of the annual subsidy for the implementation of accredited study programs (Sub-program 077 11) and subsidies for social support for students (subprogram 077 15), which includes a subsidy for motivation scholarships of students of a first and second university degree.

Tab. 2 contains the number of college students for the period 2008-2017 in the following categories of study (1st and 2nd grade together), postgraduate study (full-time) and external study (together 1st, 2nd and 3rd degree - PhD students in external studies are included because the available data did not allow us to exclude them). This categorized data simplified our analysis work.

\begin{tabular}{l|r|r|r|r} 
Tab. 1: & \multicolumn{3}{|c}{$\begin{array}{c}\text { Amount of subsidies from the state budget to public higher education } \\
\text { institutions (in } € \text { ) }\end{array}$} \\
\hline Year (i) & $\begin{array}{c}\text { Subsidy for the } \\
\text { implementation of } \\
\text { accredited programs }\end{array}$ & $\begin{array}{c}\text { Subsidy for social } \\
\text { support of students }\end{array}$ & $\begin{array}{c}\text { Subsidy for incen- } \\
\text { tive scholarships } \\
\text { (part of the grant on } \\
\text { social support) }\end{array}$ & Total \\
\hline $\mathbf{2 0 0 8}$ & $246,179,811.46$ & $49,374,327.82$ & $6,407,023.83$ & $295,554,139.28$ \\
\hline $\mathbf{2 0 0 9}$ & $278,179,490.00$ & $50,274,862.00$ & $6,670,900.00$ & $328,454,352.00$ \\
\hline $\mathbf{2 0 1 0}$ & $285,464,787.00$ & $45,552,844.00$ & $6,648,400.00$ & $331,017,631.00$ \\
\hline $\mathbf{2 0 1 1}$ & $211,589,039.00$ & $47,744,810.00$ & $6,411,100.00$ & $259,333,849.00$ \\
\hline $\mathbf{2 0 1 2}$ & $218,039,472.00$ & $52,043,774.00$ & $8,382,150.00$ & $270,083,246.00$ \\
\hline $\mathbf{2 0 1 3}$ & $218,413,704.00$ & $53,252,028.00$ & $6,869,605.00$ & $271,665,732.00$ \\
\hline $\mathbf{2 0 1 4}$ & $227,176,401.00$ & $49,175,301.00$ & $8,539,120.00$ & $276,351,702.00$ \\
\hline $\mathbf{2 0 1 5}$ & $229,480,554.00$ & $50,776,959.00$ & $8,004,803.00$ & $280,257,513.00$ \\
\hline $\mathbf{2 0 1 6}$ & $245,141,172.00$ & $48,926,749.00$ & $7,870,005.00$ & $294,067,921.00$ \\
\hline $\mathbf{2 0 1 7}$ & $247,329,145.00$ & $46,983,871.00$ & $7,994,298.00$ & $294,313,016.00$ \\
\hline
\end{tabular}

Source: Authors' processing based on the data from the Ministry of Education of the SR 


\section{Business Administration and Management}

\begin{tabular}{|c|c|c|c|c|}
\hline \multirow{2}{*}{ Year (i) } & \multicolumn{2}{|c|}{ Full-time Study $\left(\mathrm{NSF}_{\mathrm{i}}\right)$} & \multirow{2}{*}{$\begin{array}{l}\text { External form } \\
\text { of study }\left(\mathrm{NSE}_{\mathrm{Mi}}\right)\end{array}$} & \multirow{2}{*}{$\begin{array}{l}\text { Total } \\
\left(\text { NS }_{i}\right)\end{array}$} \\
\hline & I. and II. degree & $\begin{array}{l}\text { Doctoral study } \\
\left(\mathrm{NFC}_{\mathrm{i}}\right)\end{array}$ & & \\
\hline 2008 & 133,896 & 9,789 & 51,307 & 194,992 \\
\hline 2009 & 133,432 & 10,378 & 43,834 & 187,644 \\
\hline 2010 & 128,892 & 11,107 & 39,659 & 179,658 \\
\hline 2011 & 126,935 & 10,875 & 35,183 & 172,993 \\
\hline 2012 & 125,038 & 9,928 & 29,972 & 164,938 \\
\hline 2013 & 122,208 & 9,056 & 25,454 & 156,718 \\
\hline 2014 & 117,417 & 8,234 & 21,934 & 147,585 \\
\hline 2015 & 110,669 & 7,431 & 19,507 & 137,607 \\
\hline 2016 & 104,936 & 6,756 & 16,901 & 128,593 \\
\hline 2017 & 99,309 & 6,394 & 14,006 & 119,709 \\
\hline
\end{tabular}

Source: Authors' processing based on the data from the Ministry of Education of the SR

\section{Fig. 1: Allocation of the proportion of individua grants to students of the full-time form of study (in thousands of EUR)}

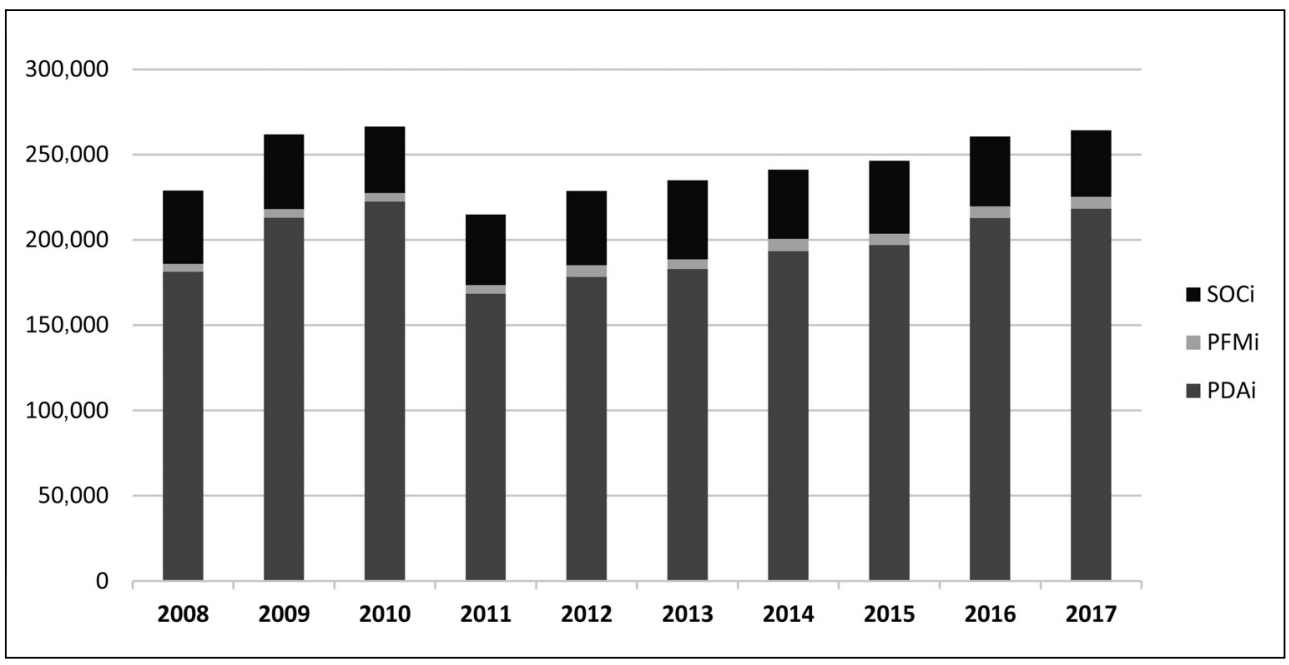

Source: Authors' processing based on the Ministry of Education of the Slovak Republic

Note: PDA - The proportion of subsidies for accredited study programs for students of the full-time study; PFM - The proportion of expenditure on motivational scholarships for students of the full-time study; SOC - Annual subsidies for social support for students in full-time study + doctoral students. 


\subsection{Results of the Calculation of the Proportion of Government Expenditure on Students in Full-Time and External Forms of Study}

The calculation of government grants per one student in section 3.2 made it much easier for us to calculate the proportion of government expenditure for both full-time students and external students. In Fig. 1 we can see the distribution of the proportions of the individual subsidies for all students included in the category "students of the full-time form of study".

In Fig. 2 we can see the distribution of the proportions of the individual subsidies for all students included in the category "students of external study". In this table, however, we do not find a column of social support expenditure for students, because students of an external form of study for these contributions are not entitled by law.

\subsection{Results of the Calculation of Annual Government Expenditure per One Student}

The results of the analysis are presented in the following Tab. 3, which shows how much of the subsidies for each sub-programme belongs to one university student in the full-time form of study and to one student in the external form of study, as well as the total sum of the state grant per one student which we aimed to calculate.

Based on our calculations, we can see that state investment in education through subsidies to universities is in the range of $€ 1,596.15$ to $€ 2,505.50$ for full-time study over the monitored period of 2008-2017, while in the case of external study range from $€ 1,297.11$ to $€ 2,136$.64. This striking difference is attributed to a reduction in the number of students between 2008 and 2017 by almost $30 \%$, which was not accompanied by a fall in government investment in higher education but by demographic change, namely by the declining birth rate since the 1990s, which reached bottom in 2002.

\section{Fig. 2: \\ Allocation of proportions of individual grants to students of external study (in thousands EUR)}

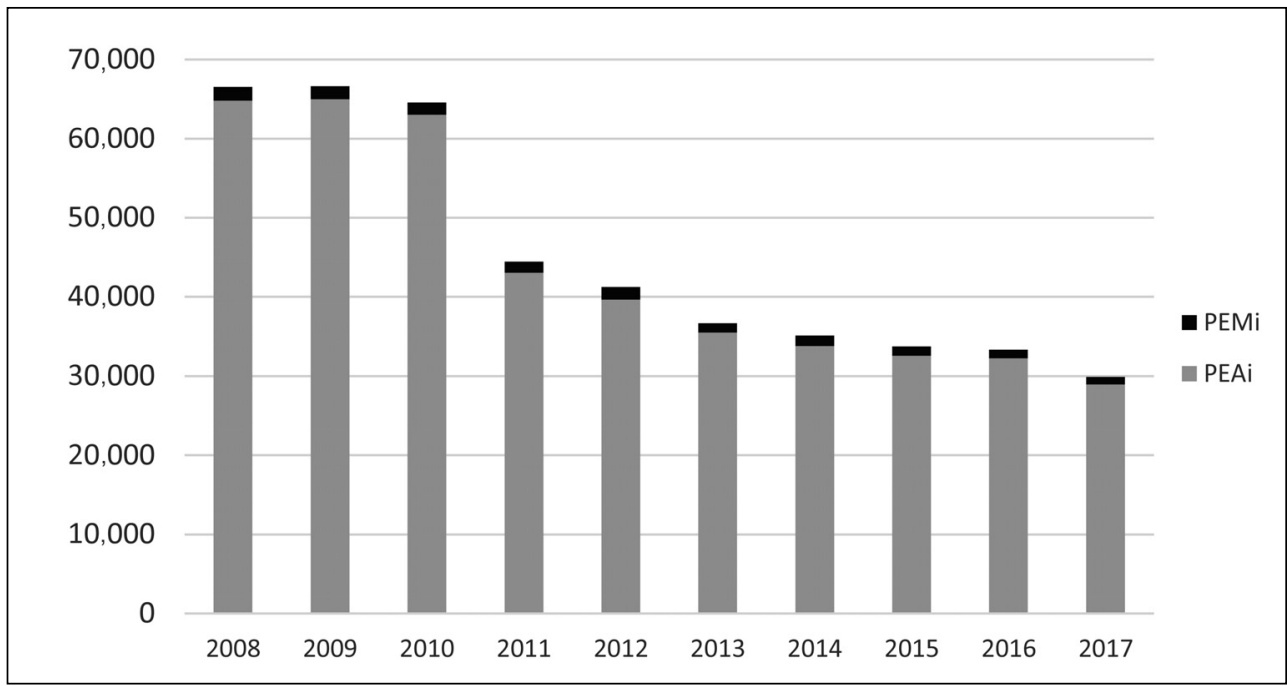

Source: Authors' processing based on the State Grants Schedule for Higher Education Institutions 2008-2017

Note: PEA - The proportion of subsidies for the implementation of accredited study programs for students of the external form of study; PEM - The proportional part of the expenses for motivational scholarships for students in the external form of study. 


\begin{tabular}{c|r|r|r|r|r} 
Tab. 3: \\
$\begin{array}{c}\text { Proportion of subsidies recalculated per one full-time study student } \\
\text { and one external study student (in } € \text { ) }\end{array}$ \\
\hline Year (i) & ASPS $_{\mathbf{i}}$ & ISS $_{\mathbf{i}}$ & \multicolumn{1}{c|}{ SOC $_{\mathbf{i}}$} & \multicolumn{1}{c}{ TAEF $_{\mathbf{i}}$} & TAEE $_{\mathbf{i}}$ \\
\hline $\mathbf{2 0 0 8}$ & $1,262.51$ & 34.59 & 299.04 & $1,596.15$ & $1,297.11$ \\
\hline $\mathbf{2 0 0 9}$ & $1,482.49$ & 37.63 & 303.21 & $1,823.32$ & $1,520.12$ \\
\hline $\mathbf{2 0 1 0}$ & $1,588.93$ & 39.44 & 277.89 & $1,906.27$ & $1,628.38$ \\
\hline $\mathbf{2 0 1 1}$ & $1,223.11$ & 39.55 & 299.93 & $1,562.59$ & $1,262.65$ \\
\hline $\mathbf{2 0 1 2}$ & $1,321.95$ & 54.07 & 323.50 & $1,699.52$ & $1,376.02$ \\
\hline $\mathbf{2 0 1 3}$ & $1,393.67$ & 46.52 & 353.35 & $1,793.55$ & $1,440.20$ \\
\hline $\mathbf{2 0 1 4}$ & $1,539.29$ & 61.28 & 323.41 & $1,923.97$ & $1,600.57$ \\
\hline $\mathbf{2 0 1 5}$ & $1,667.65$ & 61.49 & 362.17 & $2,091.31$ & $1,729.14$ \\
\hline $\mathbf{2 0 1 6}$ & $1,906.33$ & 64.59 & 367.59 & $2,338.52$ & $1,970.93$ \\
\hline $\mathbf{2 0 1 7}$ & $2,066.09$ & 70.55 & 368.86 & $2,505.50$ & $2,136.64$ \\
\hline
\end{tabular}

Source: Authors' calculations

Note: ASPS - Annual grants for the implementation of accredited study programs per one student;

ISS - Annual subsidies for incentive scholarships per student;

SOC - Annual subsidies for social support for students in the full-time study;

TAEF - Total annual state expenditure per student of the full-time form of study;

TAEE - Total annual state expenditure per student of the external form of study.

In the near future, it is likely to be expected that the proportion of the government spending on higher education per student will continue to grow, both for full-time students and part-time students.

Despite the fact that the Ministry of Education of the Slovak Republic has mechanisms to limit the admission of the number of students to full-time study, the number of students is not negotiated when allocating subsidies to universities. The increase of a number of students (although unlikely) would mean a lower grant per student, especially taking into account those government expenditures that are totally rigid with respect to the number of students. In our analysis, we have overcome this by deliberately neglecting subsidies for school development and subsidies for research, development and arts activity.

The analysis clearly shows that students are less financially demanding in the external form of a study from the perspective of the state. This is mainly because they cannot benefit from certain subsidies provided by the state. Moreover, part of the study is paid by itself but this is not included in our analysis because we focused on government investment rather than private investment.

\subsection{The Results of the Correlation between the Gross Wage} and the Level of Education Achieved

Human capital is bridged with the performance of the economy through wages through which the individual earns the proceeds of his human capital. A large number of authors are based on the returns on investment in the human capital of the individual and, at the same time, in the society as a whole. For example, Dobeš (2017) states that: "If we accept the approximation that the wage reflects the level of labour productivity, we can deduce that wage differentiation by level of education also reflects the differentiation of value added for society by education." In Tab. 4, we illustrate the average gross monthly wage expressed in the context of the education received during the period 20082016. This table output demonstrates the fact that the average height of the gross monthly wage depends on the education achieved. Directly proportional to the level of education attained, the wage in question also grows.

From all the categories compared, the largest increase in the average monthly wage for employees with higher education is obtained 


\begin{tabular}{|c|c|c|c|c|c|}
\hline Tab. 4: & $\begin{array}{l}\text { Structure of the } \\
\text { in the period yea }\end{array}$ & $\begin{array}{l}\text { erage gross } \mathrm{m} \\
2008-2016\end{array}$ & $y$ wage of & employee & lucation \\
\hline \multirow{3}{*}{ Year } & \multicolumn{5}{|c|}{ Achieved education / Average gross monthly wage (in $€$ ) } \\
\hline & \multirow{2}{*}{ Elementary } & \multirow{2}{*}{$\begin{array}{l}\text { Full secondary } \\
\text { technical }\end{array}$} & \multicolumn{3}{|c|}{ University } \\
\hline & & & I. degree & II. degree & III. degree \\
\hline 2008 & 493.03 & 758.68 & 900.05 & $1,205.11$ & $1,276.74$ \\
\hline 2009 & 501.64 & 764.00 & 928.67 & $1,255.72$ & $1,305.76$ \\
\hline 2010 & 515.00 & 788.00 & 937.00 & $1,259.00$ & $1,304.00$ \\
\hline 2011 & 536.00 & 814.00 & 930.00 & $1,278.00$ & $1,307.00$ \\
\hline 2012 & 559.00 & 841.00 & 951.00 & $1,299.00$ & $1,331.00$ \\
\hline 2013 & 587.00 & 865.00 & 969.00 & $1,331.00$ & $1,355.00$ \\
\hline 2014 & 607.00 & 909.00 & $1,021.00$ & $1,397.00$ & $1,390.00$ \\
\hline 2015 & 673.00 & 939.00 & $1,058.00$ & $1,448.00$ & $1,444.00$ \\
\hline 2016 & 640.00 & 951.00 & $1,072.00$ & $1,462.00$ & $1,458.00$ \\
\hline
\end{tabular}

Source: Authors' processing based on Statistic Office of the Slovak Republic data

by alumni of II. degree. From 2014, we can even see that the average gross monthly wage is slightly higher for employees who have a university education of II. Degree (Master's) in comparison with III. Degree (PhD). It can be seen from the statistical data evaluated, the average gross monthly wage of an employee with elementary education was $€ 640$ in 2016, ie 2.3 times lower than an employee with the education of III. degree. An employee with full secondary education had a 1.4 times higher wage than an employee with an elementary education in 2016, but 1.6 times lower wage than a comparable employee who achieved a higher education level of II. degree. In this way, we want to point out that the development of human capital over a longer period of time leads to a better financial evaluation in the form of a higher salary. Between 2008 and 2016, the average monthly wage for employees with elementary education increased by $€ 178.47$. Over the same period, the average monthly wage of employees who have completed university education of II. degree has increased by $€ 290.89$. This fact suggests that the average monthly wage rate growth is lower for employees with lower qualification than for university graduates.

The table output convincingly points out that the level of education attained, as a certain amount of human capital, also positively affects the level of wages. Higher wages represent a return not only for the individual but also for the entire national economy in the form of higher income tax revenues to a budget.

In Tab. 5 we present the results of the correlation analysis. In order to facilitate the calculation of the correlation coefficient $r$, we assigned weights between 1 and 5 for each level of education achieved. We assigned the lowest weight to elementary education and the highest weight to university education of III. degree. We then calculated the value of the correlation coefficient using the Correl function in the Microsoft Excel spreadsheet environment.

In Tab. 5 we can see that the average level of the gross monthly wage of the population of the Slovak Republic is increasing with the level of education. The lowest average monthly wage for the period 2008-2016, at $€$ 553.7, was reached by employees with elementary education. On the other hand, the highest average monthly wage at the level of $€ 1,340.5$ in the same period was achieved by employees with university education of III. degree. Therefore, there is a clear difference in wage rates between these groups of employees.

The value of the correlation coefficient $r$ is 0.969 , which means that there is a very tight correlation between the average height of the gross monthly salary and the achieved level of education in the Slovak population because the condition is fulfilled: $r=0.969>0.9$. We can also 


\section{Business Administration and Management}

\section{Tab. 5:}

Correlation between gross monthly wage and level of education in the Slovak Republic for the period 2008-2016

\begin{tabular}{l|c|r}
\multicolumn{1}{c|}{ Achieved education } & Weight of education & \multicolumn{2}{c}{$\begin{array}{c}\text { Average gross monthly wage } \\
\text { (in } € \text { ) }\end{array}$} \\
\hline Elementary & 1 & 553.7 \\
\hline Full secondary & 2 & 832.1 \\
\hline 1st degree of university & 3 & 959.4 \\
\hline 2nd degree of university & 4 & $1,310.6$ \\
\hline 3rd degree of university & 5 & $1,340.5$ \\
\hline
\end{tabular}

Correlation coefficient value $\mathbf{0 . 9 6 9}$

Source: Authors' processing based on the Statistical Office of the Slovak Republic's data

claim that there is a direct linear dependence between the variables studied because the condition is: $r=0.969>0$. This dependence represents an almost complete direct linear dependence since the value of the coefficient $r$ is almost equal to 1 . That is evident when weights are increasing lineraly, thogh it serves to emphasize the meaning.

\subsection{Results of the Analysis of the Rate of Return and the Period of Return of State Investment in Education}

Summarizing the results of previous analysis of the amount of state investment in students in individual forms of study as well as tax revenues (see Tab. 6) to the state budget that were published in another article, we were able to calculate the rate of return and return on government investment in higher education. We consider subsidies per student to be the state investment in education. We consider the difference between the annual tax receipts of individual education groups to be proceeds of these investments.

The return on investment in human capital is generally long-term. We cannot calculate data directly within one year. Such calculations would not make sense since investment in

\section{Tab. 6: Annual grants to one university student and tax revenue (in $€$ )}

\begin{tabular}{c|c|c|c|c}
\multirow{2}{*}{ Year } & \multicolumn{2}{|c|}{ Subsidies per one student } & \multicolumn{2}{c}{ Annual tax revenues } \\
\cline { 2 - 5 } & $\begin{array}{c}\text { In full-time } \\
\text { form of study }\end{array}$ & $\begin{array}{c}\text { In external form } \\
\text { of study }\end{array}$ & $\begin{array}{c}\text { Person with full } \\
\text { secondary } \\
\text { education }\end{array}$ & $\begin{array}{c}\text { Person with } \\
\text { university education }\end{array}$ \\
\hline $\mathbf{2 0 0 8}$ & $1,596.15$ & $1,297.11$ & 346.68 & 744.27 \\
\hline $\mathbf{2 0 0 9}$ & $1,823.32$ & $1,520.12$ & 596.03 & $1,100.11$ \\
\hline $\mathbf{2 0 1 0}$ & $1,906.27$ & $1,628.38$ & 725.98 & $1,221.39$ \\
\hline $\mathbf{2 0 1 1}$ & $1,562.59$ & $1,262.65$ & 752.95 & $1,223.26$ \\
\hline $\mathbf{2 0 1 2}$ & $1,699.52$ & $1,376.02$ & 907.30 & $1,422.18$ \\
\hline $\mathbf{2 0 1 3}$ & $1,793.55$ & $1,440.20$ & 839.04 & $1,254.69$ \\
\hline $\mathbf{2 0 1 4}$ & $1,923.97$ & $1,600.57$ & 890.18 & $1,364.24$ \\
\hline $\mathbf{2 0 1 5}$ & $2,091.31$ & $1,729.14$ & 849.83 & $1,223.03$ \\
\hline $\mathbf{2 0 1 6}$ & $2,338.52$ & $1,970.93$ & 876.10 & $1,276.27$ \\
\hline
\end{tabular}




\begin{tabular}{c|c|c}
\multirow{2}{*}{$\begin{array}{c}\text { Duration of study } \\
\text { (period of years) }\end{array}$} & \multicolumn{2}{|c}{ Return on investment } \\
\cline { 2 - 3 } & Full-time study & External study \\
\hline $\mathbf{2 0 0 8 - 2 0 1 3}$ & $3.26 \%$ & $5.87 \%$ \\
\hline $\mathbf{2 0 0 9 - 2 0 1 4}$ & $3.59 \%$ & $6.56 \%$ \\
\hline $\mathbf{2 0 1 0 - 2 0 1 5}$ & $2.85 \%$ & $5.11 \%$ \\
\hline $\mathbf{2 0 1 1 - 2 0 1 6}$ & $2.98 \%$ & $5.40 \%$ \\
\hline Average & $\mathbf{3 . 1 7} \%$ & $\mathbf{5 . 7 3 \%}$ \\
\hline Return period (in years) & $\mathbf{3 1 . 6}$ & $\mathbf{1 7 . 4}$ \\
\hline
\end{tabular}

education will only take effect after leaving school. However, the available data allowed us to calculate the return on investments that began in 2008, 2009, 2010 and 2011, that is, investments in students who were freshmen in these years. The return on government investment was reflected in Tab. 7 .

In Tab. 7 we can see that the return on investment in the full-time form of study is around the $3.17 \%$. For such an average return, the payback period is 31.6 years under the simplified assumption of static wage and unchanged methodology and income tax rates.

Significantly higher rates of return are achieved in the external form of study, mainly due to lower state subsidies provided to these students. The return on investment for the external form of study over the reference period is an average of $5.73 \%$, which represents the payback period of 17.4 years. Similarly, it is based on the simplified assumption that wages and tax legislation on income tax will not change.

A note towards limitations of this analysis is that we might have used different methods such as Minicer's regression like Bhuller, Mogstad and Salvanes (Bhuller, Mogstad, \& Salvanes, 2017) Another limitation might be linked to analysis that focuses on gender differences in respect to internal rate of return (IRR) as described by Hanushek, Schwerdt, Wiederhold and Woessmann (2017) or Attanasio and Kaufmann (2017). Also, different types of programs at the same university degree have different wage points, i.e. IT experts have a higher salary than most historians. All these parameters were beyond the scope of this paper.

\section{Discussion and Conclusions}

Contrary to other factors of growth, it is possible for the Slovak economy to increase the level of human capital. Slovak economy is rather undercapitalized and does not possess sufficient amounts of physical capital. This economy also does not possess a sufficient amount of capital for acquiring new technologies. Investments to human capital are counterparts to these factors that are relatively cheaper and their internal rate of return (IRR), as explained by Bhuller et al. (Bhuller et al., 2017), return on investment rate is comparable to benefit rate of physical capital.

The level of human capital in Slovakia is lower than its level in economies in Western Europe. By accepting the hypothesis that economic growth factors are also in the scope of the law of diminishing returns, it could be claimed that lower level of human capital can still provide huge growth potential without the manifestation of the law of declining yields.

Countries are usually less willing to export its human capital. Contrary to the belief, Slovakia is experiencing a decrease in human capital due to employees' immigration to countries with higher income such as Austria, Germany or even the Czech Republic. When compared to the rest of the growth factors, it is rather problematic to obtain extra human capital from domestic sources. Furthermore, this intensifies the necessity of investments to the human capital (Dobeš, Kot, Kramoliš, \& Sopková, 2017). 
Investment in education, improvement in obtaining qualifications, development of education system and science - investment to the human capital - are of high importance to our society if we want to solve current problems and improve the national budget.

Unless we invest in human capital, especially our young generation, we can be threatened by the lack of knowledge and skills in the future in order to keep up with more advanced problems that will come. While investment in the human capital can be costly in the beginning, it can prove to be a great benefit in the future, so we need to make a decision - investing or lagging behind.

During the analysis, we found that the government expenditure in the form of subsidies to higher education institutions is very rigid and uncompromising in relation to the number of students. A large part of this rigidity is explained by the fact that subsidies include grants for research and university development that do not depend on the number of students but on other factors such as approved development projects, specific grants/projects, VEGA, KEGA and other subsidies based on the competition principle. To calculate the influence of the number of students on the number of state subsidies could be an interesting follow-up to this study.

Regarding the question of whether people with higher education, whom we consider to be holders of a higher level of human capital, earn on average more than people with secondary education, we have come to the conclusion that university-educated individuals have higher wage rates than individuals with secondary education. Therefore, if one wants to maximize the future earning's potential, the study finds the II. degree of university education to be the optimal. Similarly, the state can maximize the future income tax revenues through investments into human capital and subsidies to university students.

Paper is a part of project findings, the project is VEGA 1/0961/16 - "Economic Implications and Perspectives of the Participation of the Slovak Republic in the Process of Production activities Fragmentation within Global Value Chains".

\section{References}

Act No. 595/2003, Collection of Laws of the Slovak Republic Cong. Rec. 158 (2003).
Act No. 131/2002 Col. on Higher Education and on Changes and Supplements to Some Laws., 131, Law Code Cong. Rec. (2002).

Andrejovská, A. (2013). Základné princípy účtovníctva. Košice: Elfa.

Arteaga, C. (2018). The effect of human capital on earnings: Evidence from a reform at Colombia's top university. Journal of Public Economics, 157, 212-225. https://doi. org/10.1016/j.jpubeco.2017.10.007.

Attanasio, O. P., \& Kaufmann, K. M. (2017). Education choices and returns on the labor and marriage markets: Evidence from data on subjective expectations. Journal of Economic Behavior \& Organization, 140, 35-55. https://doi.org/10.1016/j.jebo.2017.05.002.

Bánociová, A., \& Martinková, S. (2017). Active Labour Market Policies of Selected European Countries and Their Competitiveness. Journal of Competitiveness, 9(3), 5-21. https://doi.org/10.7441/joc.2017.03.01.

Becker, G. S. (1994). Human capital revisited (3rd ed.). In Human Capital: A Theoretical and Empirical Analysis with Special Reference to Education (pp. 15-28). Chicago: The University of Chicago Press.

Bhuller, M., Mogstad, M., \& Salvanes, K. G. (2017). Life-Cycle Earnings, Education Premiums, and Internal Rates of Return. Journal of Labor Economics, 35(4), 993-1030. https://doi.org/10.1086/692509.

Caplan, B. (2018). The case against education: Why the education system is a waste of time and money. Princeton: Princeton University Press.

Dobeš, M. (2000). Rate of return on investment in human capital. Individual and Society, 21(3).

Dobeš, K., Kot, S., Kramoliš, J., \& Sopková, G. (2017). The perception of governmental support in the context of competitiveness of SMEs in the Czech Republic. Journal of Competitiveness, 9(3), 34-50. https://doi.org/10.7441/joc.2017.03.03.

Edvinsson, L., \& Malone, M. (1997). Intellectual Capital: Realizing your company's true value by finding its hidden brain power. New York: HarperBusiness.

Fragouli, E. (2015). Intellectual Capital \& Organizational Advantage: an economic approach to its valuation and measurement. International Journal of Information, Business and Management, 7(1), 36-57.

Friedman, M., \& Kuznets, S. (1954). Income from Independent Professional Practice. New York: National Burreau of Economic Research. 
Galor, O., \& Tsiddon, D. (1997). The distribution of human capital and economic growth. Journal of Economic Growth, 2(1), 93124. https://doi.org/10.1023/A:100978571.

Gavurova, B., Soltes, M., \& Kovac, V. (2017). Application of Cluster analysis in process of competitevness Modelling of Slovak Repulic regions. Transformations in Business \& Economics, 16(3), 129-147.

Gavurová, B., Vagasova, T., \& Kovac, V. (2016). Competitiveness Assessment of Slovak Republic Regions. In European Financial Systems 2016. Proceedings of the 13th International Scientific Conference (pp. 175186). Brno: Masaryk University.

Hanushek, E. A., Schwerdt, G., Wiederhold, S., \& Woessmann, L. (2017). Coping with change: International differences in the returns to skills. Economics Letters, 153, 15-19. https:// doi.org/10.1016/j.econlet.2017.01.007.

Koisova, E., Masarova, J., \& Habanik, J. (2018). Regional differences in the Labour market in Slovakia and the Czech Republic. Journal of Competitiveness, 10(2), 104-117. https://doi.org/10.7441/joc.2018.02.07.

Mincer, J. (1958). Investment in human capital and personal income distribution. Journal of Political Economy, 66(4), 281-302. https://dx.doi.org/10.1086/258055.

OECD.(2017). OECD skillsoutlook2017: Skills and global value chains. Paris: OECD Publishing. https://dx.doi.org/10.1787/9789264273351-en.
Ozkan, N., Cakan, S., \& Kayacan, M. (2017). Intellectual capital and financial performance: A study of the Turkish Banking Sector. Borsa Istanbul Review, 17(3), 190-198. https://doi. org/10.1016/j.bir.2016.03.001.

Petty, R., Cuganesan, S., Finch, N., \& Ford, G. (2009). Intellectual capital and valuation: challenges in the voluntary disclosure of value drivers. https://doi.org/10.2139/ssrn.1490208.

\author{
PhDr. Daniela Palaščáková, Ph.D. \\ Technical University of Kosice \\ Faculty of Economics \\ Department of Economics \\ Slovakia \\ Daniela.Palascakova@tuke.sk
}

Ing. Gabriela Kol'veková, Ph.D. Technical University of Kosice Faculty of Economics Department of Economics Slovakia Gabriela.Kolveková@tuke.sk

Dávid Melas, MPhil. Technical University of Kosice Faculty of Economics Department of Banking and Investment Slovakia David.Melas@gmail.com 


\section{Abstract}

\section{ANALYSIS OF STATE INVESTMENTS INTO HUMAN CAPITAL IN SLOVAK REPUBLIC}

\section{Daniela Palaščáková, Gabriela Kol'veková, Dávid Melas}

This article is focused on state or government investment into human capital and on investments into universities, which are supposed to lead to an increase in wages of individuals after finishing such education. That part of income of graduates which is exceeding incomes of people with completed high school education, i.e. income bonus is, on one hand, a motivational factor for individual to study at university and on the other hand it is an opportunity for the state to achieve higher tax incomes in absolute terms due to graduates with higher salaries. The main goal of this article is to analyse investments into the human capital from the point of view of the amount of investment and its profitability, as well as from the point of view of the payback period for state investments in education. Quantitative analysis was provided by plugging in data into seven ratios/formulas. The data were from the Ministry of Education of the Slovak Republic. Results are addressing the issue of globalised education, where the fierce competition will lead to changes that will inevitably require a change in investment schemes as well as a change in behaviour and attitude towards education as such. Paper strives for achieving an advantange that is to stimulate debate on human capital in its broad sense as described in the opening of the paper. The context of this humble research is framed by technology changes in global value chains that effect economy in its structure that is turning to be more dynamic then ever.

Key Words: Global value chains, investments, capital, human resources, education.

JEL Classification: H52, H75, E24.

DOI: 10.15240/tul/001/2019-2-008 